\title{
Parents' Beliefs on Play in Preschool
}

\author{
Kristina Turk \\ Kent State University \\ $\mathrm{Kent}, \mathrm{OH}$ \\ Martha Lash \\ Kent State University \\ Kent, $\mathrm{OH}$
}

\begin{abstract}
Parents' beliefs and attitudes about early childhood play-based curriculum are influenced by personal history, socio-economic demographics, and culture. This qualitative study utilized narrative inquiry to delve into six parents' beliefs on play in preschool. Their beliefs about their children's participation in a play-based preschool and how their children's various needs were met inform the family-school partnership. Methods included narrative inquiry, observation, and documentation review. Data sources were analyzed to ascertain commonalities, differences, and emerging themes in parents' views of a play-based curriculum. Three overriding themes emerged: structure, socialization, and the reputation of their choice of Play Preschool (pseudonym). Additional analysis uncovered a deeper theme of readiness: preparation of their children for "real school," for college, and for life. The final underlying theme to emerge was fear that the child would be unprepared for school and unable to live a good life, which caused and surrounded the readiness concern. Lastly, this study provided insights for family-school partnerships in which parents' beliefs are valued.
\end{abstract}

Parents touring an early childhood center (for children aged birth to six) have frequently told us, "I just want my child to have fun!" The importance of fun, however, seems to diminish as children reach 3 or 4 years of age, a point when some parents believe preparation for "real school" should commence. Standards, standardized tests, honors, and grades will soon become their greatest concerns. Somewhere in the intervening years, the comment about fun is replaced with questions about kindergarten readiness and requests for worksheets, homework, and some sort of grade. 
Understanding parents' beliefs about how children learn is important because their support for the preschool school curriculum at the school their child attends is vital. Beliefs and attitudes about a curriculum and later decisions of parents are typically influenced by their own beliefs, experiences, and attitudes. Consequently, their views affect the implementation of programs for their young children. Thus, gaining parents' perspectives about play-based education is important to the teacher, the preschool, and the child.

Parents typically consider location, affordability, and reputation when selecting a preschool in the United States (Blau \& Robins, 1988; Camasso \& Roche, 1991; Hofferth \& Wissoker, 1992; Lash \& McMullen, 2008; Leslie, Ettenson, \& Cumsille, 2000). Based on career experiences, the authors noted that curricula focusing on care and play are desirable for infants, toddlers, and young preschoolers; yet as children approach preschool age, a "readiness" question frequently arises with parents. Concerns about learning through play and acquiring academic skills are sincere worries of many parents (Dockett \& Perry, 2015; Golinkoff, Hirsh-Pasek, \& Singer, 2006; Singer, Golinkoff \& Hirsh-Pasek, 2006).

Curious about this pervasive situation of parents' approval of play as appropriate for young children yet questioning its effectiveness for preparing three- and four-year-olds for school readiness, the two authors, each with over 20 years of preschool experience and current university instructors, were inspired to learn more directly from parents. The primary research question in this study was: What are parents' beliefs and attitudes about an early childhood play-based curriculum? The authors' aim was to identify the perspectives of six families regarding the preschool curriculum where their children attended, to learn the preschool's attempts to work with families to understand a play curriculum, and in so doing, to generate ideas and strategies to strengthen the family-school-community partnership. To reach the desired understandings, narrative inquiry (Clandinin \& Connelly, 2000) was used with multiple in-depth interviews of six families from a private, play-based preschool; observation of parents at preschool events. These, along with a review of program documents, made the study robust.

\section{Review of the Literature}

A review of literature pertaining to the research question included information on play and children's learning as well as parents' beliefs on play curriculum. This review illuminated the beliefs of teachers of young children and parents with regard to how best to educate their own children.

\section{Play and Children's Learning}

Play is essential for a developing child and provides constant experiences for learning and growing (Berk \& Winsler, 1995; Rogers \& Sawyers, 1988; Singer et al., 2006). According to Piaget (1936) children in the preoperational stage of development learn best through hands-on manipulation; play allows them to manipulate objects and their immediate environment (Chaille \& Silvern, 1996; Elkind, 1987; Rogers \& Sawyers, 1988; Singer et al., 2006; Williams \& Kamii, 1986). "Young children are natural learners; their curiosity and desire to make sense of their world lead to spontaneous, self-directed learning" (Elkind, 1987, p. 14). It has been found that play offers a multi-faceted educational impact and educates children intellectually, emotionally, socially and physically (Bergen, 2009; Thibodeau, Gilpin, Brown, Brooke, \& Meyera, 2016; Wood \& Attfied, 2005). Play enhances children's ability to master such academic content as literacy, numeracy, social competence, and cooperation (Bulotsky-Shearer, Bell, Carter \& Dietrich, 2014; Suggate, 
Schaughency \& Reese, 2013; Vallotton \& Ayoubs, 2011). Play also has an impact on emotional development, as researchers have found that, by engaging in complex forms of socio-dramatic play, children gain empathy and are able to understand others' perspectives (Lillard, Pinkham, \& Smith, 2011; Savina, 2014; Robson, 2010; Uren \& Stagnitti, 2009). In play, children are less aggressive and show more self-control and higher levels of thinking (Bodrova \& Leong, 2001; Kroll, 2016).

Interest in learning diminishes when the associated activity is directed by someone other than the child; in fact, adult-directed learning may cause children to "become dependent on adults to direct all of their activity, afraid to take initiative" (Elkind, 1987, p. 14). In contrast to adultdirected learning, play is driven by a child's intrinsic motivation to learn, promotes creative thinking (Holmes, Romeo, Ciraola, \& Grushko, 2015), and fosters problem solving (Copple \& Bredekamp, 2009; Rogers \& Sawyers, 1988). In addition, by offering choices of self-directed play activities in the classroom, educators allow children to work within their individual learning rate, decreasing the risk of pressuring them beyond their ability. Educators also encourage a love of learning in children by providing interesting activities that promote exploration and experimentation in their natural environment (Copple \& Bredekamp, 2009).

Early childhood researchers have reported that young children learn best through activities that support the development of the whole child (Elkind, 2001a) and through direct interaction with their environment (Elkind, 2001b). Before a certain age, they are simply incapable of the level of reasoning necessary for formal instruction; however, national concern with accountability, competition, testing, and "back-to-basics" overemphasizes academics and single-subject teaching (Bodrova, 2008; Miller \& Almon, 2009; Elkind, 2007; Ornstein et al., 1998; Perrone, 2000). In response to these concerns, early childhood educators can feel pressured to focus the curriculum on the teaching of academic skills (Morrison, 2000). In some programs these factors have led to narrowly defined curricula, which deny young children valuable life experiences found in play. Educators must seriously consider the differences in approaches to learning by children as opposed to adults; children, especially young ones, need play (Ginsburg et al., 2007). To engage in activity, they must be interested in it; therefore, play in the preschool should not be disregarded. If an early childhood educator can positively influence the beliefs and attitudes of parents about instruction through play, which is supported by research, she or he can cultivate their understanding of this type of curriculum. A study of parents' beliefs and attitudes about a play-based early childhood curriculum can provide information useful to teachers and administrators as they plan strategies for implementing a successful preschool program.

With the demand for "effectiveness," high test scores, and accountability occurring and perceived as occurring in the primary grades, a number of preschool administrators and educators have adopted academically focused curricula (D'Agostino \& Rodgers, 2017; Lynch, 2015; Nicolopoulou, 2011; Bodrova, 2008). In a state-wide survey conducted in Oregon, 64\% of kindergarten teachers, $61 \%$ of principals and $72 \%$ of first-grade teachers reported that formal academic instruction was more prevalent in kindergarten at the time of the survey than it had been 10 to 20 years earlier (Hitz \& Wright, 1988). When teachers and administrators overemphasize academics, they often do so at the expense of play, which is valuable to children's learning and development (Alliance for Childhood, 2010; Copple \& Bredekamp, 2009). Survey participants may have considered play less important than formal instruction for cognitive development and creative play less relevant to the development of thinking and problem solving.

Early childhood educators have shown concern about the type of instruction used in their programs (Epstein, 2007; Hatch \& Freeman, 1988; Sisson \& Iverson, 2014). Practices used in 
preschool and prekindergarten typically reflect an environmentalist-behaviorist view, even though teachers have reported holding other views (Daniels \& Shumow, 2003). Programs for kindergartners have also changed and often emphasize academic skills previously reserved for older children (Freeman \& Hatch, 1989; Hitz \& Wright, 1988; Karweit, 1988; Shepard \& Smith, 1988). In a study on teaching practice, two thirds of early childhood teachers implemented programs in conflict with their early childhood learning philosophies (Hatch \& Freeman, 1988). Early childhood experts have long urged that programs for young children should provide for the development of social, emotional, physical, cognitive, and creative skills; however, the findings noted above reflect a shift in this advice. Even in cases where teachers consider play as a serious activity that contributes to learning, they do not know how to translate their beliefs into practice (McLane, 2003; Ranz-Smith, 2012; Ploof, 2014). In short, a gap exists between researchers' recommendations and teaching practice (Copple \& Bredekamp, 2009; Logue, Eheart, \& Leavitt, 1996).

\section{Parents' Beliefs on Play}

Not surprisingly, parents' beliefs on play reflect cultural variations (Roopnarine, 2011). When considered globally, parents in western, technologically developed societies were more likely to embrace play as important for children's cognitive and social development as well as to see themselves as play partners to children; whereas, families in more agricultural societies saw play as incidental to the developing child (Roopnarine, 2011) Play serves a scholastic function in technologically developed societies as compared to assisting in the reproduction of culture-specific tasks and behaviors in agricultural and hunting-gathering societies (Roopnarine, 2011). This cultural diversity occurs even within nations, as evidenced by a study of cross-cultural notions of play in childhood among parents based in two economically diverse residential metropolitan areas in India (Singh \& Gupta, 2012). Findings indicated that all parents had an unquestionable belief in an epistemic grounding of play in children's lives; however, parents begin to question play timings and children's engagement with play when faced with the demands of schooling embroiled in a childhood dominated by academic achievement, which suppressed parents' intuitive leanings towards play. The school-led social environment controlled play and shaped notions of childhood, forcing parents to socialize children for school performance. This study also showed that the availability of technology in children's lives rendered gadgets as treasured play objects among certain social groups, replacing the make-believe games of the past.

The two most prominent competing views on parents' belief systems are the constructivist and the cultural (Harkness \& Super, 1997). According to the former, parents' beliefs are selfconstructed: Views of parents regarding the nature of their child's development are dependent upon how they make sense of both their experiences and cultural norms surrounding child rearing and parenting. The latter has also been recognized in the field of child learning.

Parents' belief systems are related both to more general cultural belief systems and to the particular experiences of raising individual children in a specific time and place; they represent a convergence of the public and the private, the shared, and the personal. (Harkness \& Super, 1997, p. 17)

According to the constructivist view the belief systems of parents are modified from time to time as a result of the multiple experiences parents share with their children. Parents adjust their "internal representations" about their roles as parents according to the demands of culture and as a response to daily experiences in a specific place and time. Parents' representations or constructs 
change and are reorganized usually as a result of dramatic economic and social upheaval (Harkness \& Super, 1997).

Until the time of this writing, the manner in which parents' belief systems were influenced by demographic and social variables was unclear despite the existence of studies that supported the influence (Mills, 2009). Some have theorized, however, that the existence of various belief systems present in groupings based on gender, race, or communities possibly explains why research studies indicate that parents' beliefs are significantly related to social variables. In one study, 13 poverty-level mothers of preschool-aged children participated in a study to examine how parents experiencing intergenerational poverty view their role as parents and the value they place on children's play. The study concluded that these parents believed their role was to guide their children to develop into "good" people. Parents valued play and its role in child development but did not feel that it was their role to play with their children (Smith, Stagnitti, Lewis, \& Pepin, 2015). However, they did note that something was gained as a result of engaging in play with their child, including feeling happy, satisfied, a sense of achievement, involved, included, enjoyment and having fun. Parents shared that they experienced a positive feeling of seeing their child develop, by having good conversations with them and the opportunity to act in a non-disciplinary role (Smith, Stagnitti, Lewis, \& Pepin, 2015).

As a result of differences in beliefs about education, confidence in children, and intelligence, parents may have differing belief structures regarding children's learning and development. The belief systems of immigrants, for example, exhibit cultural variations with regard to their children and preschool education (Tobin, 2016; Tobin, Arzubiaga, \& Adair, 2013). Those differences can explain why so many studies of parents' aspirations for their children relate to demographic variables. Demographic factors and cultural context should be included in the explanation of parent beliefs. Low-income African American mothers of children attending Head Start were the participants in a study conducted by Fogle \& Mendez (2006). The researchers found that parents with higher education levels held more supportive beliefs about play and child development, and that those with lower education levels stressed more academically focused beliefs. Play beliefs were also not subject to a child's age or gender, suggesting parents have similar play beliefs for both boys and girls, as well as for younger and older preschool children. This sample of low-income, African American mothers generally held a positive view of play and an appreciation of its significance for child development. These findings are consistent with other research documenting that parental goals for early childhood instruction vary by education as well as income (Fogle \& Mendez, 2006).

In a study of the perceptions of parents and educators on the preschool curriculum and current practices in Canada, researchers gathered data from focus-group discussions and surveys of parents and teachers as well as reviews of documents associated with preschool programs (Corter \& Pelletier, 1995). The findings revealed that both parents and educators were confident that a play-based, child-centered preschool curriculum was the practice most effective in promoting early childhood development; however, some parents also expressed approval of the current practice of incorporating more academics.

One two-part study, involving 1,130 American mothers and 99 preschool educators, revealed the beliefs of American mothers regarding play-based learning and their preferences for the way preschool education should be delivered to their children. In Study 1 mothers' beliefs about play and the learning that can be derived from it were investigated and revealed differing conceptions of play. Some mothers believed that play consisted of unstructured, goal-oriented activities that require the use of the imagination. Other mothers considered only unstructured 
activities as play; still others were generally uncertain about the nature of play. The majority of the mothers attributed learning value to play but attributed learning only to those activities that fit their descriptions of play. Generally, more learning value was credited to structured (field trips, museums) compared to unstructured activities (free play, expressive play). Study 2 delineated the way educators and parents defined play. Educators considered structured activities non-play, ascribing less learning value to them but rated the learning value of unstructured activities higher (Fisher, Hirsch-Pasek, Golinkoff, \& Gryfe, 2008).

Another study showed that parents generally do not perceive a play-based curriculum to be an effective curriculum program (Morrow \& Rand, 1991). In fact, these researchers argued, play can be incorporated into preschools as recreation or as an ice breaker during the day's activities; yet parents doubted whether their child would learn anything while playing. Results contradicted those of another study in which the majority of parents believed that a play approach is the best early learning method (Qadiri \& Manhas, 2009). Furthermore, parents who were asked whether they considered the curriculum of the preschool when enrolling their child reported that they had not; instead they relied on the recommendations of friends and the popularity of the school among those in their circle of friends (Moore \& Derman-Sparks, 2003). In addition, parents are increasingly anxious about standards (Saracho, 2002). A survey showed that parents often ask how soon their child would be able to read and inquired about the achievement rates of students in terms of reading and mastery of academic skills. Parents also believed that knowing the alphabet, counting, and using pencils are essential skills needed for kindergarten (West 1993). This may indicate that parents often lean toward academics-based curricula or traditional schools because of the emphasis placed on improving academic skills and performance. Despite the research base for developmental programs and play in education, educators have faced opposition from parents and society with regard to play in their classrooms. Adults who have not been educated in child development theories may struggle to grasp how play in the classroom actually fosters learning and growth. Parents no longer remember what it was like for them to learn about the world around them when they were young children, a phenomenon known as childhood amnesia, which explains why they have difficulty understanding the benefits of play as a learning process (Elkind, 2005). Consequently, some parents may avoid or question programs that entail play-driven curricula.

\section{Methodology}

The research question for this study was as follows: What are parents' beliefs and attitudes about an early childhood play-based curriculum? Our narrative inquiry methodology, which entailed listening carefully to parents, was designed to contribute to a broader conception of families and their beliefs about caring for their children. Our aim is to add to the literature regarding various families' beliefs and desires, inform teachers and schools of those beliefs, and shore up the foundation needed to improve the family-school partnership. Although it is one small qualitative study, in combination with the research of others, it can strengthen the knowledge base, expand the parent component in the family-school partnership, and share applied teaching suggestions with regard to parents' beliefs.

This section contextualizes the study with a description of the research setting, participant recruitment and overview of participants, and adherence to confidentiality. The section on research methods explains narrative inquiry and justifies its use and how it was enacted along with our rationale for adding observation and review of documents. Trustworthiness of the data and data analysis complete this section and lead into our findings. 


\section{Research Setting}

This study took place at a private, for-profit, National Association for the Education of Young Children-accredited preschool that adhered to the principles and requirements of a quality play-based preschool. We chose Play Preschool (pseudonym) as the primary location for the participant selection for the following reasons: (a) personnel at Play Preschool have used a playbased curriculum for the past nine years, and (b) the school had strong parent involvement. Play Preschool was located in a Midwestern suburban community, where 48\% of the 4,481 family households comprised high-income college graduates with an average household income of $\$ 154,704$. Neither author was employed or had any supervisory roles at the research setting; both authors had directed similar type centers and wanted to understand this population better. We wanted parents to share freely without concern for the care of their children. When we approached an administrator at Play Preschool to secure it as a research site, we explained the Institutional Review Board (IRB) and confidentiality processes along with the parameters of the study and secured approval for Play Preschool to serve as the research site.

\section{Recruitment and Overview of Participants}

Participants were parents of children enrolled at Play Preschool. The parents of the 20 children in the preschool classroom were invited to participate in the research study through a message that appeared in the school's electronic newsletter. Interested parents were asked to complete a short demographic survey, which included the following: (a) parent's age, (b) ethnicity, (c) highest level of education attained, (d) length of time the child had been enrolled at the preschool, and (e) total number of the participant's children and the number enrolled at the preschool. The demographic survey was returned to the researchers via email. We planned to use purposeful sampling (Rubin \& Rubin, 2005) to choose participants who represented the larger population of parents at Play Preschool; however, because of the number of surveys returned, purposeful sampling was unnecessary. We originally planned to interview five parents for this research project. Twenty-two surveys were sent out, and eight were returned. Of the eight responding, one potential participant's survey and participation was excluded for unethical comments made prior to the interview process during an initial phone discussion to set up an interview time. Another participant returned the survey after the other participants were well immersed in the second round of interviews. The exact process used for the other participants in the earlier interviews would have been difficult to replicate for this late participant. From the pool of eight applicants, we decided to keep all six participants as opposed to five as originally proposed. The background, culture, age, and gender of participants were representative of the school population as described on the website.

As shown in Table 1, the participants, although all White with middle to upper incomes, showed diversity in their families (Lash, 2014). An examination of this group of six families revealed that three of the current family situations involved separation, divorce, and in two cases second marriages, resulting in blended families. For example, Mike was a single dad with primary parenting responsibilities. Mike stated that he had to adjust his perceptions of fatherhood when he became a single parent after having grown up in a two-parent household with a stay-at-home mother:

Nobody told me how to deal with a child or nobody told me how to deal with this situation [single parenthood]. That's life. I mean, it's scary, but you're so right about that. When you 
have the experience at first [of two parents] and then you have to go backwards, it's a little difficult.

All of the participants became parents in their late twenties at the earliest, and five of the six completed their college education and began careers before establishing families. Three of the mothers were in their 40s; two of them were in their mid-40s before giving birth. To outsiders, the families may appear privileged, and certainly privilege accompanies Whiteness and income; yet we learned from the demographics and from their stories that challenges and fears were also part of their lives. 
Table 1. Participants' Backgrounds and Basic Results of the Historical Interview at time of study.

\begin{tabular}{|c|c|c|c|c|c|c|}
\hline Name & Mike & Laura & Jennifer & Donna & Connie & Patty \\
\hline Age & 30 & 48 & 30 & 47 & 32 & 41 \\
\hline $\begin{array}{l}\text { Parent } \\
\text { Info }\end{array}$ & Single dad & Married & Married & Married & Married & Married \\
\hline $\begin{array}{l}\text { Child } \\
\text { Info }\end{array}$ & $\begin{array}{l}\text { Only child: } \\
\text { son }\end{array}$ & $\begin{array}{l}2 \text { HS sons \& } \\
1 \text { at Play PS }\end{array}$ & 1 daughter & $\begin{array}{l}2 \text { step- } \\
\text { daughters } \\
1 \text { son } \\
\text { (together) at } \\
\text { Play PS }\end{array}$ & $\begin{array}{l}4 \text { children: } \\
3 \text { boys; } 1 \\
\text { girl. } \\
1 \text { former } \\
\text { Play PS + } 1 \\
\text { current at } \\
\text { Play PS }\end{array}$ & $\begin{array}{l}1 \text { daughter } \\
\text { from } \\
\text { previous } \\
\text { marriage. } \\
\text { Son \& } \\
\text { daughter } \\
\text { (current } \\
\text { husband) at } \\
\text { Play PS }\end{array}$ \\
\hline $\begin{array}{l}\text { Parent } \\
\text { Ed }\end{array}$ & Dad: B.S. & $\begin{array}{l}\text { Mom: MAEd } \\
\text { Dad: MD }\end{array}$ & $\begin{array}{l}\text { Mom: BS } \\
\text { Dad: MAEd }\end{array}$ & $\begin{array}{l}\text { Mom: BA } \\
\text { Dad: Army }\end{array}$ & $\begin{array}{l}\text { Mom: No } \\
\text { college } \\
\text { Dad: No } \\
\text { college }\end{array}$ & $\begin{array}{l}\text { Mom: No } \\
\text { college } \\
\text { Dad: MS }\end{array}$ \\
\hline $\begin{array}{l}\text { Grand- } \\
\text { parent } \\
\text { Info }\end{array}$ & $\begin{array}{l}\text { Stay-at- } \\
\text { home mom }\end{array}$ & $\begin{array}{l}\text { Stay-at-home } \\
\text { mom }\end{array}$ & $\begin{array}{l}\text { Raised by } \\
\text { (deaf) } \\
\text { grandparent } \\
\text { after mom } \\
\text { died }\end{array}$ & Mom: RN & $\begin{array}{l}\text { Raised by } \\
\text { dad } \\
\text { (divorce) }\end{array}$ & $\begin{array}{l}\text { Stay-at- } \\
\text { home mom }\end{array}$ \\
\hline $\begin{array}{l}\text { Earliest } \\
\text { Memory }\end{array}$ & $\begin{array}{l}\text { PS } \\
\text { classroom }\end{array}$ & K Teacher & $\begin{array}{l}\text { K Sticker } \\
\text { progress } \\
\text { chart }\end{array}$ & $\begin{array}{l}\text { K Teacher, } \\
\text { Classroom }\end{array}$ & $\begin{array}{l}\text { PS: did not } \\
\text { enjoy }\end{array}$ & $\begin{array}{l}\text { 1st grade } \\
\text { Teacher }\end{array}$ \\
\hline Influence & $\begin{array}{l}\text { Reputation, } \\
\text { structure, } \\
\text { socialization } \\
\text { for school }\end{array}$ & $\begin{array}{l}\text { Caring } \\
\text { teachers, } \\
\text { warm } \\
\text { environment, } \\
\text { reputation, } \\
\text { socialization }\end{array}$ & $\begin{array}{l}\text { Reputation, } \\
\text { structure, } \\
\text { socialization, } \\
\text { visits }\end{array}$ & $\begin{array}{l}\text { Caring } \\
\text { teachers, } \\
\text { reputation, } \\
\text { environment, } \\
\text { socialization }\end{array}$ & $\begin{array}{l}\text { Past } \\
\text { experience }\end{array}$ & $\begin{array}{l}\text { Reputation, } \\
\text { individual } \\
\text { attention } \\
\text { for } \\
\text { learning }\end{array}$ \\
\hline $\begin{array}{l}\text { Child } \\
\text { Start } \\
\text { Age }\end{array}$ & 3 yrs. & 3 yrs. & 2 yrs. & $1 \mathrm{yr}$. & 3 yrs. & 2 yrs. \\
\hline $\begin{array}{l}\text { Yrs. } \\
\text { Here }\end{array}$ & 1 & 2 & 1.5 & 1.5 & 2 & 2 \\
\hline
\end{tabular}

\section{Confidentiality}

This study was approved by the IRB, and all participants signed an approved release form and knew of their right to remove themselves from the study at any time without penalty. The research site and each participant were assigned a pseudonym. Anonymity was preserved during 
transcriptions and throughout the writing process. Only the participant and the researchers were aware of the identity corresponding to a pseudonym.

\section{Research Method: Narrative Inquiry with Observation and Review of Documents}

Narrative inquiry. Clandinin and Connelly's (2000) three-dimensional narrative inquiry space was designed to elicit an understanding of meaning in the context of parents' stories. They concurred with Dewey (1938/1998), who stated that the ultimate aim of research is the study of human experience; thus, a three-dimensional narrative inquiry space served as a guide to draw out the content of human lives in order to understand life experiences. Personal and social dimensions point both inward and outward - inward "toward the internal conditions, such as feelings, hopes, aesthetic reactions, and moral dispositions[; and outward] toward the existential conditions . . . [moving backward and forward points] to temporality - past, present, and future" (Clandinin \& Connelly, 2000, p. 50). This methodology allows for identification of the parents' beliefs and practices. In looking both forward and backward, we gain an understanding of how individuals' life histories, as well as outside factors, inform their current beliefs and attitudes toward play-based curriculums.

Each of the six parents participated in three interviews: a life history interview, a currentcontext interview that included a summary of their present situation, and a follow-up interview. During interviews participants sometimes react unusually to the presence of a researcher, who may unduly influence the data generated. To minimize this type of influence, researchers can allow an appropriate period of time for themselves and participants to get used to each other (Patton, 1990, p. 473). This at times proved to be easier for some than for others. A few participants, eager to talk immediately, provided lengthy responses; others required more casual initial conversation and coaxing. On many occasions participants shook their heads or shrugged their shoulders as opposed to articulating an answer. In those instances, we attempted to restate the question, probing for a verbal answer with "Are you saying ... ?" or "Is it correct to say. . . ?" Parents were interviewed according to the proposed platform to ensure a variety of perceptions. The questions were intended to measure the depth of the parents' individual responses when questioned on their views of the subject. The interviews were focused and untimed, providing the opportunity for parents to explain their perspectives in depth. All interviews were conducted at sites preferred by the participants, for example, Play Preschool conference room, local coffee shops, or cafes; then they were recorded, transcribed, and shared with the participants to verify the accuracy of each interview.

The narrative in-depth interview, which can elicit far richer information than a survey, offered a means to clarify and validate participant responses. Individual behaviors can be understood only by comprehending individuals' interpretations of the world around them (Cohen, Manion, \& Morrison, 2000); therefore, meaningful social action must be interpreted from the point of view of the actors or the people involved in that particular situation. Parents who have already enrolled their child in a play-based preschool may naturally feel more strongly about it than parents who have not sent their child to a play-based preschool (Bryman, 2004). Through narrative inquiry we sought to understand particular details in a historically and socially bound context (Clandinin \& Connelly, 2000).

From the social constructivist perspective, experiences are significant to meaning making. In a three-dimensional framework for studying how participants' past, present, and future contexts influence their beliefs and attitudes, experience is significant (Clandinin \& Connelly, 2000). Drawing from narrative inquiry supported understanding of how parents' beliefs and attitudes about a play-based curriculum informed the three dimensions. This approach was attractive 
because it provided the opportunity for the parents' voices to be heard. We used narrative inquiry to explore how their decisions to enroll their children in facility with a play-based curriculum evolved and were influenced. Their shared stories revealed their motivations.

Observation and review of documents. We also decided to explore how the preschool positioned itself as a play preschool with the families. To do this, we reviewed program documents and attended parent meetings that were held regularly. Observations were made during a personal tour of Play Preschool and during several events held at the preschool, including parent-teacher conferences, PTO meetings, and some parent celebrations, such as Community Games and Stepping Up for the Environment. The intent was to enhance interviews with observations of these events by documenting which parents attended parent-teacher conferences, PTO meetings, and parents' information meetings and by noting which concerns they shared, any consistency in attendance at these meetings, and how parent participation among the six parents differed during celebratory activities with their children as opposed to conferences and informational evenings. During observations, we focused on interactions relevant to this study. As a safeguard, participants were granted the right to exclude researchers from any setting without penalty. Participant observations helped us examine the manner in which participants manifested their beliefs and attitudes about the curriculum and play.

Table 2 shows the types of curricular meetings and social events offered by Play Preschool during this study and what each of our participants attended. These meeting observations generated follow-up questions for interviews. For example, one parent meeting, Learning through Play, consisted of a guest speaker with a total of 15 parents in attendance; all but one of the participants in this study attended. The presentation, which explained what play is, what it means, what it looks like, what children do, and what children learn, led us to follow-up questions: What exactly does play mean to you? Do you feel learning occurs during play time? Parents also viewed their children in the play curriculum center. This opportunity provided a foundation for parents to further familiarize themselves with the play-based curriculum; it highlighted how learning occurs during play activities. This experience directly supported parents in recognizing how play leads to content understanding. In view of this direct teaching, we thought it would be an ideal time to determine whether this had any influence on their beliefs and thus led us to probe this topic more deeply in interviews. 
Parents' Beliefs on Play in Preschool

Table 2. Events Offered/Attended

\begin{tabular}{|l|c|c|c|c|c|c|}
\hline Name/ Event & Mike & Laura & Jennifer & Donna & Connie & Patty \\
\hline $\begin{array}{l}\text { Parent mtg } \\
\text { (Sept.) }\end{array}$ & $\mathrm{X}$ & $\mathrm{X}$ & $\mathrm{X}$ & $\mathrm{X}$ & $\mathrm{X}$ \\
\hline $\begin{array}{l}\text { Parent- } \\
\text { teacher } \\
\text { conference } \\
\text { (Nov.) }\end{array}$ & $\mathrm{X}$ & $\mathrm{X}$ & $\mathrm{X}$ & $\mathrm{X}$ & $\mathrm{X}$ & $\mathrm{X}$ \\
\hline $\begin{array}{l}\text { Community } \\
\text { Games (Feb.) }\end{array}$ & $\mathrm{X}$ & $\mathrm{X}$ & $\mathrm{X}$ & $\mathrm{X}$ & & \\
\hline $\begin{array}{l}\text { Stepping up } \\
\text { for the } \\
\text { Environment } \\
\text { (March) }\end{array}$ & $\mathrm{X}$ & $\mathrm{X}$ & $\mathrm{X}$ & $\mathrm{X}$ & $\mathrm{X}$ \\
\hline $\begin{array}{l}\text { Parent mtg } \\
\text { (April) }\end{array}$ & $\mathrm{X}$ & $\mathrm{X}$ & $\mathrm{X}$ & $\mathrm{X}$ & $\mathrm{X}$ \\
\hline $\begin{array}{l}\text { PTO mtg } \\
\text { (May) }\end{array}$ & & $\mathrm{X}$ & $\mathrm{X}$ & $\mathrm{X}$ & $\mathrm{X}$ \\
\hline $\begin{array}{l}\text { Mother's } \\
\text { Day Tea } \\
\text { (May) }\end{array}$ & & $\mathrm{X}$ & $\mathrm{X}$ & & $\mathrm{X}$ \\
\hline $\begin{array}{l}\text { Parent- } \\
\text { teacher } \\
\text { conference } \\
\text { (May) }\end{array}$ & & & & & \\
\hline
\end{tabular}

To have a more complete understanding of what Play Preschool provided families regarding its philosophy, we gathered and analyzed documents, such as the parent handbook, newsletters, newspaper articles featuring Play Preschool, research articles distributed to the parents, school literature including its mission statement, student rights, and student portfolio. Through these artifacts we gained specific knowledge of the information parents received as well as a strong impression of the way preschool information was presented. Clear statements about the play-based curriculum appeared in the materials, including the following:

1. "Play-based preschools better help young children develop skills necessary for future learning."

2. "When compared to academics-based programs, children in play-based programs outperform the others socially and academically."

3. "Parents, do your homework!"

4. "Studies show 3- and 4-year-olds thrive on an environment focused on play."

We determined that Play Preschool-in classroom environments, programs, and written documents-promoted a play-based program. The curriculum theory espoused by the staff at Play Preschool, according to its literature and website, was based on the works of Piaget, who believed that the developing child builds cognitive structures for understanding and responds to experiences 
in his or her environment. Like Piaget, Play Preschool staff members believed that play behavior is a vehicle for cognitive stimulation.

\section{Trustworthiness of the Data}

Despite growing agreement that "value-free interpretive research is impossible" (Denzin, 1989 , p. 23), the criticism that qualitative researchers may unknowingly impose their values, beliefs, or biases onto the participants and thus unduly influence the data is perhaps the most common criticism of any qualitative inquiry (Patton, 1990). The apparent surplus of researcher influence expected in qualitative inquiries may be the result of the inherent frankness and candor with which qualitative research exposes the inevitability of such influence (Patton, 1990). Because the researcher seeks to observe and interpret meanings in context, finalizing research strategies before data collection has begun is neither possible nor appropriate (Patton, 1990).

Validity, or the correct or credible description of the conclusion, explanation, or interpretation (Maxwell, 2005), includes not only triangulation and member checking, but also deciphering specific alternative interpretations and explanations. These areas include researcher bias and reactivity; furthermore, validity tests can be performed by the researcher to include intensive, long-term involvement, rich data, respondent validation, intervention, discrepant evidence and negative cases, triangulation, quasi-statistics, and comparison (Maxwell, 2005). We kept those issues and areas of concern in mind throughout this research.

Credibility in the naturalist sense must show that the researcher strives to represent multiple constructions adequately; this includes reconstructions and how they are pursued and presented (Lincoln \& Guba, 1985). To achieve credibility, the researcher must first carry out the inquiry in such a way that the probability that the findings will be found to be credible is enhanced and second, to demonstrate the credibility of the findings by having them approved by the constructors of the multiple realities being studied. (Lincoln \& Guba, 1985, p. 296)

To ensure trustworthiness, we used peer examination-debriefing and member checking (Creswell, 2007; Lincoln \& Guba, 1985; Merriam, 1998). In using peer examination-debriefing, we shared data and emerging assertions with a review committee. Using peer debriefing in this way not only assisted us in keeping our perspective in check by offering the perspectives of outside reviewers while providing support in the construction of emerging methodological design but also assisted us in ensuring that methods were dependable and confirming the trustworthiness of findings. Debriefing sessions occurred periodically throughout the data collection and analysis stages, and pseudonyms for every person were used at all times.

We also used member checking to ensure the credibility of this research (Creswell, 2007; Lincoln \& Guba, 1985; Merriam, 1998). The researchers shared transcribed interviews with each corresponding participant for accuracy and commentary, allowing participants to correct any factual errors, clarify intentions, and provide feedback on emerging assertions. Member checking occurred at the end of each interview.

In addressing issues of the transferability of this research, the researchers maintain that the naturalist cannot specify the external validity of an inquiry; he or she can provide only the thick description necessary to enable someone interested in making a transfer to reach a conclusion about whether transfer can be contemplated as a possibility. (Lincoln \& Guba, 1985, p. 316)

Although the intent was to share the stories of how a particular group of parents came to understand and make the decisions for their child to attend a preschool that adheres to an early childhood play-based curriculum, these findings may lend some insight into similar contexts. In making this research transparent, thick descriptions were provided, not only of the participants and 
their historical and contextual influences but also of who we are as researchers and the methods for collecting data and process of emerging assertions. Such thick description allows the reader to make individual judgments about transferability.

\section{Data Analysis}

We analyzed the gathered data using the qualitative method, an inductive approach that starts with a rough definition of research questions, data collection, coding, saturating categories, and exploring relationships among categories (Bryman, 2004). The subprocesses involved in this data analysis method were data reduction, data display, and conclusion drawing (Huberman \& Miles, 1998). After collection, the data were first reduced to component parts in order to make complicated issues understandable (Bernard, 1988, as cited in Huberman \& Miles, 1998). We spent a significant amount of time reading each transcribed interview, reviewing observation notes, and recording our understanding as the study unfolded to draw connections among emerging themes. A benefit to analyzing data throughout the data-collection process was that our analysis served to inform us how to continue to ask questions to elicit better information. Creswell (2007) suggests that by conducting data analysis throughout the research process, the researcher can use early forms of analysis to drive subsequent data collection. For example, after observations, we reviewed our notes closely to develop further questions and points for additional discussion or to establish clarity during follow-up interviews.

Throughout this stage, we carefully coded transcribed interviews and notes for emerging themes (Wellington, 2000). We used a categorical aggregation (Stake, 1995) to organize and analyze common threads among participants and across interviews and observations. During categorical aggregation with regard to parents' beliefs and attitudes about a play-based curriculum, particular attention was given to common as well as exceptional descriptions of significant influences identified throughout their stories and to meanings associated with their current beliefs and attitudes.

Second, data display allowed us to conceptualize the material as organized and assembled data. After identifying themes we focused our attention on the personal narratives of each participant. With this approach, we were able to improve our understanding of the significant role each theme played throughout their lived stories. Direct interpretation was used carefully to examine instances that emerged as significant for individual participants (Stake, 1995).

The third process was drawing conclusions, which involved interpreting and giving meaning to data (Wellington, 2000). These processes provided a useful starting point for data analysis in this investigation, but analyzing qualitative data is messier and more complicated than these three processes suggest. Data analysis must involve immersing oneself in the data, reflecting upon it, taking it apart, synthesizing it, relating and locating the data, and presenting it (Wellington, 2000). We used these strategies during the data analysis of this research.

\section{Findings: Parents' Beliefs on Preschool and Play}

Our six participants considered socialization, structure, and reputation the driving forces behind their decisions to place their children at Play Preschool. Structure can help children feel safe, and preschool educators build in daily routines for consistency and predictability. To the study participants, however, structure meant academics associated with skill and drill and sitting quietly. They sent their children to preschool because they believed that attending would give them 
a head start on academic skills. Parents felt preschool was a rite of passage, and an academic preschool would prepare children for the challenges of education; these participants seemed to be caught up in the achievement panic. Thus, for them structure equaled academics, which equaled good grades, which in turn equaled admission to a good college, which equaled a good career, which equaled a good life. Table 3 captures the participants' wording along with the goals they revealed for their children in Play Preschool and beyond.

Table 3. Participants' Reflections on Goals for Children \& Preschool Selection Criteria

\begin{tabular}{|c|c|c|c|}
\hline Participants & $\begin{array}{c}\text { Plans for children's } \\
\text { futures }\end{array}$ & Preschool outcome & $\begin{array}{c}\begin{array}{c}\text { Criteria for selecting } \\
\text { preschool }\end{array} \\
\end{array}$ \\
\hline Mike & $\begin{array}{l}\text { To be a good person, } \\
\text { attend college, } \\
\text { communicate well } \\
\text { with others }\end{array}$ & $\begin{array}{c}\text { To be able to interact } \\
\text { with others; structure and } \\
\text { direction }\end{array}$ & $\begin{array}{l}\text { Structure, good } \\
\text { reputation }\end{array}$ \\
\hline Jennifer & $\begin{array}{l}\text { Stay true to herself and } \\
\text { her likes; to have } \\
\text { opportunities that } \\
\text { make her happy and } \\
\text { achieve success }\end{array}$ & $\begin{array}{l}\text { Gains respect for others } \\
\text { and learning; early } \\
\text { foundation for } \\
\text { educational future. }\end{array}$ & $\begin{array}{l}\text { Reputation, visits, } \\
\text { structure, socialization }\end{array}$ \\
\hline Patty & $\begin{array}{l}\text { To be happy, to excel } \\
\text { in whatever she wants }\end{array}$ & $\begin{array}{l}\text { Prepare for elementary } \\
\text { school; follow directions, } \\
\text { foundation for next level, } \\
\text { knowing numbers and } \\
\text { letters, socialization }\end{array}$ & Tour, structure \\
\hline Connie & $\begin{array}{l}\text { To grow up to be the } \\
\text { best person he can be, } \\
\text { to follow his dreams, } \\
\text { to be smart to utilize } \\
\text { every opportunity }\end{array}$ & $\begin{array}{c}\text { To learn to get along } \\
\text { with others; to be ready } \\
\text { for } K\end{array}$ & Past experience \\
\hline Laura & $\begin{array}{l}\text { To be successful, to } \\
\text { find something that } \\
\text { makes him happy, to } \\
\text { feel good about } \\
\text { himself, and to provide } \\
\text { for himself and family }\end{array}$ & $\begin{array}{l}\text { Socialization, foster } \\
\text { cooperative behavior; } \\
\text { learn about the teacher's } \\
\text { role in education in order } \\
\text { to gain the most }\end{array}$ & $\begin{array}{l}\text { Caring teachers, warm } \\
\text { environment that } \\
\text { fosters early learning } \\
\text { and exploration, } \\
\text { reputation, and } \\
\text { socialization } \\
\text { opportunities }\end{array}$ \\
\hline Donna & $\begin{array}{c}\text { The luxury to follow } \\
\text { his heart and passion, } \\
\text { not just work }\end{array}$ & $\begin{array}{l}\text { To get along with others, } \\
\text { listen to others, respect } \\
\text { others, learns basics to } \\
\text { build upon, a head start } \\
\text { to education }\end{array}$ & $\begin{array}{l}\text { Care, reputation, } \\
\text { caring teachers, } \\
\text { individual attention }\end{array}$ \\
\hline
\end{tabular}

The findings as they relate to preschool as preparation for the future involved academic readiness, social readiness, behavioral readiness, and parents' fears associated with the need for readiness for the future. Analysis of the findings indicate that all six parents were impacted by their own past experiences in education. Depending on whether their experiences were positive or 
negative, they chose either a path for their children similar to the one they had followed or a completely different path for them, respectively. Parents who enjoyed preschool and later schooling were eager to enroll their children in facilities similar to those they had attended, but those who had negative experiences with early childhood education enrolled their children for other reasons, such as to fill a need for care, to have their children to fit in with other children in the neighborhood, to place their children in a school with a good reputation, to ensure their children opportunities for experiences different from their own, and to fill a perceived void in their own capabilities.

\section{Readiness}

Throughout their interviews parents conveyed middle-class social and cultural norms of valuing education, as foregrounded in the human capital perspectives in early childhood education (Bloch/Swadener/Canella, 2014; Polakow, 2012). They saw the need to inform their children about what society expects from them and how to conduct themselves accordingly; in turn, we extrapolate that educators must advocate for children as human beings in that society, requiring fair treatment with rights to be respected. Scientific knowledge became privileged over subjective knowing (feelings, intuition) that comes from active involvement in the environment (Lubeck, 2002). Play is not optional but instead fundamental to a child's development. The United Nations recognized this and, as a result, formed the international treaty that sets universal standards for the rights of children. It serves as a benchmark for which a nation's treatment of its children can be measured. Adopted November 20, 1989, Article 31 of the United Nations' Convention on the Rights of the Child (CRC) states:

1. States Parties recognize the right of the child to rest and leisure, to engage in play and recreational activities appropriate to the age of the child and to participate freely in cultural life and the arts.

2. States Parties shall respect and promote the right of the child to participate fully in cultural and artistic life and shall encourage the provision of appropriate and equal opportunities for cultural, artistic, recreational and leisure activity.

In contrast to the CRC, these parents shared beliefs more aligned with the human capital perspectives in early childhood education. During her interviews Patty placed more emphasis on the importance of academic preparation than on any other factors. She noted:

They [children] need the exposure to a classroom base if you will. . . . I think kids that don't get that may have a harder time adapting to kindergarten. So I think if they need the preschool environment prior to kindergarten, at least it can help. I think PS [preschool] is a practice elementary school. Kids need to learn to follow directions, sit, and work and get along with others. Georgia is a very strong-willed little girl. She needs to learn that she's not the boss.

Children are a vulnerable group, often denied their human rights, a situation that must be addressed by all governments to ensure that the rights of the children are protected (Bergen, 2002). In addition, the respondents indicated that some of them were unaware of certain issues affecting their children while in school, such as their right to play, current testing, and standardized 
curriculum issues. Jennifer favored standards, standardized testing, and structured learning even at this level. She said:

It's more, again, more like the structure and less about the skills, including academia. Not that they don't teach her great things at Play Preschool, and they do it in all different ways and challenge her because they do. But I liked tests; I did well on them, so I think they need to be ready for that.

Laura and Donna, two participants who preferred a play-based curriculum or what they knew of it at Play Preschool, had memories about their time in school spent sitting at desks, being quiet, listening to teachers, and having a lot of homework. Although the play-based curriculum sounded like best practice for young learners, the concern that they may not be adequately prepared for the next level plagued all the parents and strongly influenced their choices for their children, including these two parents who agreed they liked play. Donna said:

I think kids learn everywhere: grocery store, friends' houses, et cetera, so yes, I know they're learning through play; but I also think that preschool is the opportunity to learn basics to build on, to provide a good start to his education, and that I'm not sure happens through play.

Laura asserted:

Play to me is interacting with others in different types of atmospheres and circumstances or areas set up to reinforce [it]. I absolutely believe learning occurs during play time, but I also know as I have two older sons what happens when they get to school. Sadly, it's not play. So whether I believe it in or not-it's hard to 100\% support because it's not reinforced at the next level.

The anxiety about grades was high among parents - despite their belief that testing did not reflect the true level of children's knowledge, as is noted in the literature (Saracho, 2002; West, 1993; Dockett \& Perry, 2015; Golinkoff, Hirsh-Pasek, \& Singer, 2006; Singer, Golinkoff \& HirshPasek, 2006; Singh, \& Gupta, 2012). All six respondents agreed that their children needed more academic preparation from a very young age. Such beliefs derive from the importance placed on grades and GPAs during enrollment at a university or college and in the pursuit of a job. With the emphasis on academic achievement and grades, many parents predictably feel that the academicsbased curriculum is what preschools should implement (MacNaughton \& Williams, 2009). All six parents, regardless of how they felt about a play-based curriculum, felt the pressures associated with academic achievement, GPAs, standardized testing, and assessment.

As a result, parents face the dilemma of either letting their children develop at their own pace and in a way with which they are most comfortable, or preparing them in a more structured and disciplined fashion to further the perception of getting ready for "real" school. Even though only four participants had had a glimpse of what was to come (by having older children), all six parents mentioned structure as an important aspect of early childhood education.

Donna had not attended preschool, so her earliest memory of school was that of kindergarten. Her fondest memories related to structure: She remembered her teacher, her desk, and the classroom. She described her experience as a "great time," which to her meant sitting at a 
desk and listening to the teacher. When asked whether she would want a similar experience for her son she said, "Yes, for sure!" She continued:

There was not a lot of free choice, for what I remember the whole day was structured . . . even structured play. I believe we had gym time, so that was really the only free play we had, so I don't recall there being fun, free play. I remember it being very structured.

Donna stated that it was fun to have structured play and studies, indicating that she equated structure with academics. She enjoyed the process of listening to teachers and learning through study. Judging from her past experience, Donna stated that she would like the same experience for her son Aaron. She said:

I think structure is very important even to little ones like the importance of schedule when they're infants and routines, so I do want him to have some sort of structure. I know that if it's a true curriculum, there's going to be structure to it anyways. I am assuming that Aaron is going to be the same way, to learn by doing. So if there's something that's going to have structure with hands-on learning. That's the experience I want him to have.

After many such conversations with all of the participants, we inferred that parents equated structure and academics. Preparation for academics was a theme that developed during interviews with the participants. All six stated that they perceived the primary importance of preschool education to be the preparation of their children for their educational futures, in contrast with Dewey (1938/1998), who believed that education is not preparation for life: Education is life itself. Keeping parents informed of issues that affect the rights of their children is the responsibility of educators. Doing so builds trust and provides support throughout their educational experience. Overall, parents focused on their children's academic success and school readiness as a guarantee of future success in all aspects of life. The thinking seems to be that if they do well in preschool, they will do well in elementary school; if they do well in elementary school, they will be successful in high school, ensuring a good college education, leading to a good career and a good life.

\section{Fears}

Parents regard preschool as preparation for the future-academic readiness, social readiness, and behavioral readiness - but they also harbor some fears about their children's future. Overall, their fears that their children may experience difficult lives were understandable after we listened to their stories. Aware of the complexities of their own lives, they realized the necessity of benefiting from personal experience, doing one's best in school, enjoying what one does for a living, following one's own nature, and improving oneself continuously. Parents' fears are rooted in a natural desire to help their children avoid their own mistakes and to protect them from all adversities; however, these fears often accompany reluctance to realize that children have the right to make their own decisions about what they want and who they want to be (Johnson, 2011). The interviewed parents who expressed fears about their children's future lives need to accept that their children may have their own individual talents and dreams, which may be completely different from their own.

In their interviews parents indicated looming fears surrounding their children's achievement, quality of life, future career, and social acceptance, showing that they wanted to protect their children from misfortune, hardship, dissatisfaction, and unhappiness, all of which, 
according to them, begin in preschool. They believe that providing a strong, solid send-off at the beginning of their academic journey may pave the way for their success in school and in life.

Patty stated:

I was visibly shocked at the tuition, but after visiting other places, ... I got it. You know, you get what you pay for. And, for sure, Georgia would be prepared for school. And funny, though, when I told my neighbors that Georgia was going to Play Preschool, they were like "Whoooa, the Harvard of preschools!"

In the interviews parents revealed their concerns about their children's personalities, believing that their children should be positively influenced by society (mainly parents, teachers, and peers), learn from their personal experiences, actively interact with others, adopt some adult character traits (such as responsibility, self-consciousness, and reasonableness), and play in order to explore the world. Furthermore, the parents were interested in their children's communication, encouraging them to make friends and to achieve success in their social surroundings; however, their answers also implied their desire for their children to be conscious of the potential deterrents to face-to-face communication inherent in technology, encouraging face-to-face conversations over online conversations. Concern about socialization generated by the complexity of adult life and marginalization as a member of society were revealed by all as a common thread in the need for preschool education. The interviewed parents primarily feared that their children would not be accepted in their social surrounding. For example, Mike believed that his son needed to be a communicative person to be a decent member of society. He stated:

I think that there's always going to be a need for face-to-face communication, and that's something I tell him that all the time. . . . That's the part the scares me. You don't know how to have those conversations, and you don't know how to interact with people, and that scares me. I do think that it's going to be a difficult, difficult road. I think it will be a difficult road when it comes to friendships, business interactions, and relationships.

The father and mothers who participated in this study were caring and well-intentioned parents, seeking to provide their children with the tools and foundation to be successful in school; however, academic pressures were already a burden to the children. Did they know their numbers and letters? Should they be given worksheets to complete? When will they read? These were questions that caused parents to fret over how to give their children an edge in their education because academic-based instruction was the tradition these adults knew. Patty stated:

Well, and I've also told Beth [Georgia's teacher] that, you know, I'm going to get more involved, too. So now that I know what letter she's working on, we'll work on that letter. I know what letter we did last week and the week before that. So I won't go ahead, but we won't go back. ... I I am very concerned. She's going to kindergarten in the fall, and she doesn't know any letters. None. My other daughter knew all her letters at this age. I've requested worksheets to do at home with Georgia so I can teach her letters. 
Parents' Beliefs on Play in Preschool

Laura stated:

Like it or not, it is the reality, the future, for these kids as I have seen with the older boys in high school to remain motivated, to do his best. I have no reason to think that Mario will not bring home good grades. I guess I expect As, but grades really don't mean anything. It is a standard means of evaluation .... To me, I guess that means he achieved his goals according to them. ... I I think, on the other hand, I want to see him engaged, active, exploring, and investigating, like really enjoying learning. That's my measurement.

Parents perceived a play-based early childhood curriculum in various ways. Some of the interviewed parents welcomed playing and having fun as an avenue for learning, but others thought that school should be a serious institution with limited play time. Laura held a positive view of play:

I feel if you are active in your child's life, ... if you talk to them and you share your expectations, you support, guide, and listen to them, ... . unless there is a problem, learning should be fun and should happen automatically.

The participants' answers reflected two types of fears related to the absence of the children's achievements. The first type is associated with a parent who thinks that a child's reallife achievements (especially in nonacademic spheres) do not necessarily depend on academic progress and who fears that too much attention is given to test scores. Another type of parent fear is the belief that academic progress is paramount for individual achievements in life; if the child demonstrates poor performance at school and does not work hard to progress academically, the likelihood of attending a reputable college or university and landing a successful career is slim.

The interview results indicated that parents' fears related to children's achievement, quality of life, future career, and social acceptance were inevitable and even natural. Aware of their own mistakes in life, parents want their children to avoid negative experiences. Parents' desires to make their children's lives better were readily apparent in their fears. Adults know that facing failure is challenging and painful, so they tend to protect their children from life's adversities as much as they can. In this context, parents encourage their children to succeed in learning and to develop their cognitive skills as well as their social skills wherever possible (e.g., in a kindergarten, at home, on the playground).

\section{Building Family-School Partnerships in View of Parents' Beliefs}

As shown in this research, the six participants had a strong desire to prepare their children for academic success, socialization, and the future. Thus, additional research on child advocacy may best focus on the following questions: Have events in contemporary society caused people to fixate on outcomes to the extent that children are over-prepared? Have pressures to prepare children for success prevented them from "being kids" and developing appropriately? Should children be involved in the process of making decisions about their early education? Talking to them would be a helpful means to understanding the interests, weaknesses, and strengths of children. Is children's participation in decisions about their education a new cultural trend? Jennifer held firm beliefs that children's voices were not as critical to this conversation: "So the more she can learn to listen to adults and follow their directions in different situations, the better. 
I think. It is important." Thus, Jennifer wanted her child to follow the teachers' and parents' examples and behave accordingly and - in her view-responsibly.

The study findings demonstrate that parents perceive preschools as lacking in following cultural trends in terms of inculcating norms and behavioral patterns in children (e.g., their perception academic readiness). At the same time, parents perceive preschools as overemphasizing children's rights to play in preschool settings (e.g., without realizing the academic connection that children are making through play.) Hence, implications for teacher educators relate to the special training of preschool educators on these issues. To be more specific, in both types of teacher education programs, academic and play-based, teachers are urged to gain special knowledge and skills that help to reinforce social norms of morality and behavior in children and to ensure protection of children's rights in the early childhood setting.

Children bring a variety of experiences into the classroom. These differences should generate the starting point for teacher educators to generate new visions to teach young children in a global society (Grieshaber.\& Ryan, 2006). In addition, teacher education programs should introduce into preschool educators' work practices that embrace family counseling and parent information regarding the key culture-related issues occurring in preschools. If these initiatives were in place, preschool education would follow educational trends, to not only respond to parents' needs but also to strengthen the children's individuality.

Listening for understanding versus listening to respond is an important skills for teachers to develop when working with families (Frank, 2011; Kroeger \& Lash, 2011;Turner-Vorbeck \& Miller Marsh, 2008; Rishel, 2008; Turner-Vorbeck, 2008; Edwards, Pleasants, \& Franklin, 1999). Although teacher preparatory programs usually emphasize play as the primary preschool learning mode, the parents in this study revealed a belief that preschool provides preparation for the future in terms of academic readiness, social readiness, and behavioral readiness. All the parents admitted that they wanted their children to play, but their misunderstanding of the connection of play and learning needs to be addressed. Identifying the learning associated with play in a manner that parents can connect to future success is a skill teachers need to embrace.

Empathic understanding is another important attribute for teachers to embrace in view of parents' fears. Real or imagined, parents' fears must be acknowledged to move forward through the conversations about readiness. Addressing these fears now is an important part of the teacher's role. Assuring them that their child will be prepared for the next level and that targeted skills can be mastered without paper and pencil becomes a teacher's responsibility that requires time, trust, confidence and proof.

Once the family-school relationship has been built upon teachers' listening for understanding and empathy, the teachers' trustworthiness with families will foster conversation. For example, Jennifer stated:

I think the thing that I was most influenced by was the interaction that I observed between teachers and the children. Communication is what I do for a living. I think it is very important, and I felt that there would be a strong home-school communication. I went there because I noticed [Play Preschool] on the way home. I looked up the phone number and found there were a lot of them. I didn't know that. So I guess location played into my initial decision to contact them.

Teachers should have a well-articulated plan, which they are prepared to explain and discuss. This will help to merge teachers' and families' expectations of roles. Any pressure from 
parents to minimize the importance of play and to provide worksheets and homework will serve as a basis for a different discussion that shows the merits of play. Engaging in conversation with parents regarding a teaching pedagogy that does not promote worksheets and homework may not be easy in today's test-driven society, but the stage will be set for demonstrating readiness through play.

We hope that preschool teachers can allay parents' fears and show them how their children learn through play and how such learning can be applied and serve them well on standardized tests and in life. Teachers who have developed a sense of commitment and purpose for their work and are capable of providing meaningful instruction directly related to their students and their lives are in a position to help students explore and construct knowledge about the world around them. We urge preschool teachers to collaborate with children's families on the curricular philosophy of the school; confidently offer support, resources, and research to facilitate parents' understanding; and guide their expectations. 


\section{References}

Alliance for Childhood. (2010, November). Restoring play and playful learning to U.S. kindergartens. Retrieved from http://www.allianceforchildhood.org/sites/ allianceforchildhood.org/files/file/Kindergarten_brief.pdf

Bergen, D. (2002). The role of pretend play in children's cognitive development. Early Childhood Research and Practice, 4(1), 2-15.

Bergen, D. (2009). Play as the learning medium for future scientists, mathematicians, and engineers. American Journal of Play, 1 (4), 413-428.

Berk, L. E., \& Winsler, A. (1995). Scaffolding children's learning: Vygotsky and early childhood education. Washington DC: National Association for the Education of Young Children.

Blau, D. M., \& Robins, P. K. (1988). Child-care costs and family labor supply. Review of Economics and Statistics, 70, 374-381.

Bloch, M. N./Swadener, B.B./Cannella, G. S. (eds.) (2014). Reconceptualizing early childhood care and education, critical questions, new imaginaries and social activism: A reader. Brussels, Belgium: Peter Lang.

Bodrova, E. (2008). Make-believe play versus academic skills: A Vygotskian approach to today's dilemma of early childhood education. European Early Childhood Education Research, 16(3), 357- 369.

Bodrova, E., \& Leong, D. J. (2001). The tools of the mind project: A case study of implementing the Vygotskian approach in American early childhood and primary classrooms. Geneva, Switzerland: International Bureau of Education.

Bredkamp, S. (2009). Developmentally Appropriate Practice in Early Childhood Programs. (Revised Edition). National Association for the Education of Young Children.

Bredekamp, S., \& Copple, C. (1997). Developmentally appropriate practice in early childhood programs (Rev). Washington, DC: National Association for the Education of Young Children.

Bryman, A. (2004). Social research methods (2 ${ }^{\text {nd }}$ ed.). Oxford, UK: Oxford University Press.

Bulotsky-Shearer, R. J., Bell, E. R., Carter, T. M., Dietrich, \& Sandy, L. R. (2014). Peer play interactions and learning for low-income preschool children: The moderating role of classroom quality. Early Education and Development 25(6), 815-840.

Camasso, M. J., \& Roche, S. E. (1991). The willingness to change to formalized child care arrangements: Parental considerations of cost and quality. Journal of Marriage and the Family, 53, 1071-1082. 
Parents' Beliefs on Play in Preschool

Chaille, C., \& Silvern, S. B. (1996). Understanding through play. Childhood Education, 72(5), 274.

Clandinin, J. D., \& Connelly, F. (2000). Narrative inquiry: Experience and story in qualitative research. San Francisco, CA: Jossey-Bass.

Cohen, L., Manion, L., \& Morrison, K. ( 2000). Research methods in education ( $5^{\text {th }}$ ed.). London, UK: Routledge Falmer.

Convention on the Rights of the Child (n.d.). United Nations Human Rights: Office of the High Commissioner for Human Rights. Retrieved from http://www.ohchr.org/en/ professional interest/pages/crc.aspx

Copple, C., \& Bredekamp, S. (2009). (Eds.). Developmentally appropriate practice. Washington, DC: National Association for the Education of Young Children.

Corter, C., \& Pelletier, J. (1995). Parent perspectives and participation in exemplary kindergarten practice. Paper presented at the Annual Meeting of the American Educational Research Association, San Francisco, CA.

Creswell, J. W. (2007). Qualitative inquiry and research design: Choosing among five approaches ( $2^{\text {nd }}$ ed.). Thousand Oaks, CA: Sage.

D’Agostino, J. V., \& Rodgers, E. (2017). Literacy achievement trends at entry to first grade. Educational Researcher, 46(2), 78-79.

Daniels, D. H., \& Shumow, L. (2003). Child development and classroom teaching: A review of the literature and implications for educating teachers. Journal of Applied Developmental Psychology, 23(5), 495-526.

Denzin, N. K. (1989). Applied social research methods series. Newbury Park, CA: Sage.

Dewey, J. (1998). Experience and education. New York, NY: Macmillan. (Original work published 1938).

Dockett, S., \& Perry, B. (2015). Transition to school: Times of opportunity, expectation, aspiration, and entitlement. In J. M. Iorio \& W. Parnell (Eds.), Rethinking readiness in early childhood education: Implications for policy and practice (pp. 123-139). New York, NY: Palgrave MacMillian.

Edwards, P. A., Pleasants, H. M., \& Franklin, S. H. (1999). A Path to Follow: Learning to Listen to Parents. Heinemann; NH.

Elkind, D. (1987). Miseducation: Preschoolers at risk. New York, NY: Knopf. 
Elkind, D. (2001a). The hurried child: Growing up too fast too soon ( $3^{\text {rd }}$ ed.). Jackson, TN: Perseus.

Elkind, D. (2001b). Young Einsteins: Much too early. Education Next, 1(2), 8-15.

Elkind, D. (2005). Viewpoint. Early childhood amnesia: Reaffirming children's need for developmentally appropriate programs. Young Children, 60(4), 38-40.

Elkind, D. (2007). The power of play: How spontaneous, imaginative activities lead to happier, healthier children. Cambridge, MA: Da Capo Press.

Epstein, A. S. (2007). The intentional teacher: Choosing the best strategies for young children's learning. Washington, DC: National Association for the Education of Young Children.

Fisher, K. R., Hirsch-Pasek, K., Golinkoff, R. M., \& Gryfe, S. G. (2008). Conceptual split? Parents' and experts' perceptions of play in the $21^{\text {st }}$ century. Journal of Applied Developmental Psychology, 29(4), 305-316.

Fogle, L. M., \& Mendez, J. L. (2006). Assessing the play beliefs of African American mothers with preschool children. Early Childhood Research Quarterly, 21, 507-518.

Frank, Carolyn. (2011) Ethnographic interviewing for teacher preparation and staff development: A field guide. New York, NY: Teachers College Press.

Freeman, E. B., \& Hatch, J. A. (1989). What schools expect young children to know and do: An analysis of kindergarten report cards. The Elementary School Journal, 89, 595-605.

Ginsburg, K. R., \& the Committee on Communications and the Committee on Psychosocial Aspects of Child and Family Health. (2007, January 1). The importance of play in promoting healthy child development and maintaining strong parent-child bonds. Pediatrics, 119(1), 182-191. Retrieved from http://www2.aap.org/pressroom/ playfinal.pdf

Golinkoff, R. M., Hirsh-Pasek, K., \& Singer, D. G. (2006). Why play = learning: A challenge for parents and educators. In D. G. Singer, R. M. Golinkoff, \& K. Hirsh-Pasek (Eds.), Play=learning: How play motivates and enhances children's cognitive and socialemotional growth (pp. 3-12). New York, NY: Oxford University Press.

Grieshaber, S. \& Ryan, S. K. (2006). Beyond certainties: Postmodern approaches and research about the education of young children. In B. Spodek \& O. Saracho (Eds.). Handbook of Research on the Education of Young Children, 533-553. Lawrence Erlbaum Associates.

Harkness, S., \& Super, C. (Eds.). (1997). Parents' cultural belief systems: Their origins, expressions, and consequences. New York, NY: Guilford. 
Parents' Beliefs on Play in Preschool

Hatch, J. A., \& Freeman, E. B. (1988). Kindergarten philosophies and practices: Perspectives of teachers, principals, and supervisors. Early Childhood Research Quarterly, 3(2), 151166.

Hitz, R., \& Wright, D. (1988). Kindergarten issues: A practitioner's survey. Principal, 67(5), 2830. Retrieved from http://www.socresonline.org.uk/socresonline/2/3/8.html

Hofferth, S. L., \& Wissoker, D. A. (1992). Price, quality, and income in child care choice. The Journal of Human Resources, 27, 70-111.

Huberman, A. M., \& Miles, M. B. (1998). Data management and analysis methods. In J. Van Gils (Ed.), Several perspectives on children's play: Scientific reflections for practitioners (pp. 11-27). London, UK: Garant.

Johnson, E. (2011). The children's bill of emotional rights: A guide to the needs of children. Lanham, MD: Jason Aronson.

Karweit, N. (1988). A research study: Effective preprimary programs and practices. Principal, $67(5), 18-21$.

Kroeger, J., \& Lash, M. (2011). Asking and listening and learning: Toward a more thorough method of inquiry in home-school relations. Teaching and Teacher Education, 27, 268277.

Kroll, L. R. (2016). Early childhood curriculum development: the role of play in building selfregulatory capacity in young children. Early Child Development and Care, in press, 1-15.

Lash, M. (2014). What is a family? In K. Cushner \& J. K. Dowdy (Eds.), From the margins to the mainstream: Enhancing social awareness in social studies classroom (pp. 5-12). Lanham, MD: Rowman Littlefield.

Lash, M., \& McMullen, M. (2008). The child care trilemma: How moral orientations influence the field. Contemporary Issues in Early Childhood, 9(1), 36-48.

Leslie, L. A., Ettenson, R. \& Cumsille, P. (2000). Selecting a child care center: What really matters to parents? Child \& Youth Care Forum, 29, 299-322.

Lillard, A., Pinkham, A. M., \& Smith, E. (2011). Pretend play and cognitive development. In The Wiley-Blackwell Handbook of Childhood Cognitive Development. (2nd ed.). WileyBlackwell, Oxford, UK.

Lincoln, Y., \& Guba, E. (1985). Naturalistic inquiry. Newbury Park, CA: Sage.

Logue, M. E., Eheart, B. K., \& Leavitt, R. L. (1996). Staff training: What difference does it make? Young Children, 41, 8-9. 
Lynch, M. (2015). More play please: The perspective of kindergarten teachers on play in the classroom. American Journal of Play, 7 (3), 347-369.

Lubeck, S. (2002) Deconstructing “child development knowledge" and "teacher preparation". Early Childhood Research Quarterly, 11(6), 147-167.

MacNaughton, G., \& Williams, G. (2009). Techniques for teaching young children: Choices for theory and practice (3rd ed.). French Forest: Pearson Education Australia.

Maxwell, J. (2005). Qualitative research design. Thousand Oaks, CA: Sage.

McLane, J. B. (2003). “Does not.' "'Does too.' Thinking about play in the early childhood classroom. Erikson Institute Occasional Paper, 4. Retrieved from http:// fwww.erikson.edu/files/nonimages/mclaneoccasional paper.pdf.

Merriam, S. B. (1998) . Qualitative research and case study applications in education. San Francisco, CA: Jossey-Bass.

Miller, E. \& Almon, J. (2009). Crisis in the Kindergarten: Why children need to play in school. Alliance for Childhood. College Park, MD: Alliance for Childhood.

Mills, A. (2009, August 3). Early childhood education takes to the outdoors. Edutopia. Retrieved from http://www.edutopia.org/early-childhood-outdoor-education-waldkindergarten

Moore, T., \& Derman-Sparks, L. (2003). Giving children global views. Early Childhood Today, $18(3), 40-49$.

Morrison, J. (2000). Fundamentals of early childhood education. Upper Saddle River, NJ: Merrill.

Morrow, L. M., \& Rand, M. K. (1991). Promoting literacy during play by designing early childhood classroom environments. The Reading Teacher, 44(6), 396-402.

Nicolopoulou, A. (2011). The alarming disappearance of play from early childhood education. Human Development, 53(1), 1-4.

Ornstein, P. A., Merritt, K. A., Baker-Ward, L., Furtado, E., Gordon, B. N., \& Principe, G. (1998). Children's knowledge, expectation, and long-term retention. Applied Cognitive Psychology, 12, 387-405.

Patton, M. Q. (1990). Qualitative research and evaluation methods (2 ${ }^{\text {nd }}$ ed.). Newbury Park, CA: Sage.

Perrone, V. (2000). Lessons for new teachers. Boston, MA: McGraw Hill.

Piaget, J. (1936). Play, dreams, and imitation in childhood. New York, NY: Norton. 
Parents' Beliefs on Play in Preschool

Ploof, R. L. (2014). Connection between early childhood teachers' beliefs and practices regarding play (Doctoral dissertation). Retrieved from https://search-proquest com.proxy.library.kent.edu/docview/1557706825 (Order No. 3625821).

Polakow, V. (2014). None for you: Children's capabilities and rights in profoundly unequal times. In Bloch, Marianne, N./Swadener, Beth Blue/Cannella, Gaile S. (eds.) (2014) Reconceptualizing Early Childhood Care and Education, Critical Questions, New Imaginaries and Social Activism: A Reader. Brussels, Belgium: Peter Lang.

Qadiri, F., \& Manhas, S. (2009). Parental perception towards preschool education imparted at early childhood education centers. Studies on Home and Community Science, 3(1), 19-24.

Ranz-Smith, D. J. (2012). Explicating the place of play: Resolving dilemmas of research-to practice. Journal of Early Childhood Education, 33 (1), 85-101.

Rishel, T. J. (2008). From the principal's desk: Making the school environment more inclusive. In T. Turner-Vorbeck, \& M. Miller Marsh (eds). Other Kinds of Families: Embracing Diversity in Schools, 46-63. New York, NY: Teachers College Press.

Robson, S. (2010). Self-regulation and metacognition in young children's self-initiated play and reflective dialogue. International Journal of Early Years Education, 18 (3). 227-241.

Rogers, C. S., \& Sawyers, J. K. (1988). Play in the lives of children. Washington, DC: National Association for the Education of Young Children.

Roopnarine, J. L (2011). Cultural variations in beliefs about play, parent-child play, and children's play: Meaning for childhood development. In A. Pellegrini (Ed.) Oxford Handbook of the Development of Play, pp. 19-37. New York, NY: Oxford University Press.

Rubin, H. J., \& Rubin, I. S. (2005). Qualitative interviewing: The art of hearing data (2 ${ }^{\text {nd }}$ ed.). Thousand Oaks, CA: Sage.

Saracho, O. N. (2002). Teachers' roles in promoting literacy in the context of play. Early Childhood Development and Care, 172(1), 23-34.

Savina, E. (2014). Does play promote self-regulation in children? Early Child Development and Care, 184 (11).

Shepard, L. A., \& Smith, M. L. (1988). Kindergarten readiness and retention: A qualitative study of teachers' beliefs and practices. American Educational Research Journal, 25, 307-333.

Singer, D. G., Golinkoff, R. M., \& Hirsh-Pasek, K. (Eds.). (2006). Play=learning: How play motivates and enhances children's cognitive and social-emotional growth. New York, NY: Oxford University Press. 
Singh, A. \& Gupta, D. (2012). Contexts of childhood and play: Exploring parental perceptions. Childhood: A Journal of Global Child Study, 19 (2), 235-250.

Sisson, J. H., \& Iverson, S. V. (2014). Disciplining professionals: A feminist discourse analysis of public preschool teachers. Contemporary Issues in Early Childhood, 15(3), 217-230. Retrieved from www.wwwords.co.uk/CIEC.

Smith, R. L., Stagnitti, K. Lewis, A. J., \& Pepin, G. (2015). The views of parents who experience intergenerational poverty on parenting and play: A qualitative analysis. Child Care Health Development, 41(6), 873-881.

Stake, R. E. (1995). The art of case study research. Thousand Oaks, CA: Sage.

Suggate, S. P., Schaughency, E. A., \& Reese, E. (2013). The contribution of age and reading instruction to oral narrative and pre-reading skills, Early Childhood Research Quarterly, 28 (1), 33-48.

Thibodeau, R.B., Gilpin, A.T., Brown, M. M. \& Meyer, B. A. (2016). The effects of fantastical pretend-play on the development of executive functions: An intervention study. Journal of Experimental Child Psychology, 145, 120-138.

Tobin, J., Arzubiaga, A. E., \& Adair, J. K. (2013). Children crossing borders: Immigrant parent and teacher perspectives on preschool for children of immigrants. New York, NY: Russell Sage Foundation.

Turner-Vorbeck, T. (2008). From textbooks to the teacher's lounge: The many curricula of family in schools. In T. Turner-Vorbeck, \& M. Miller Marsh (Eds.). Other Kinds of Families: Embracing Diversity in Schools, 176-191.New York, NY: Teachers College Press.

Turner-Vorbeck, T., \& Miller Marsh, M. (2008). Other Kinds of Families: Embracing Diversity in Schools. New York, NY: Teachers College Press.

Uren, N., \& Stagnitti, K. (2009). Pretend play, social competence and involvement in children aged 5-7 years: The concurrent validity of the Child-Initiated Pretend Play Assessment. Australian Occupational Therapy Journal, 56(1), 33-40.

Wellington, J. (2000). Education research: Contemporary issues and practical approaches. London, UK: Continuum.

West, J. (1993). Readiness for kindergarten: Pent and teacher beliefs. Washington, DC: National Center for Education Statistics.

Williams, C., \& Kamii, C. (1986). How do children learn by handling objects? Young Children, 42(1), 23-26. 
Parents' Beliefs on Play in Preschool

Wood, E. A., \& Attfield. J. (2005). Play, learning and the early childhood curriculum. (2nd Ed.). London, Great Britain: Paul Chapman Publishing. 